\title{
The Trend Toward Industrial Democracy
}

\author{
By E. P. Cheyney, LL.D. \\ University of Pennsylvania
}

I SUPPOSE the fact that we are all experimenting in various ways, in various forms of industrial democracy, is an unquestionable one. But the question that appeals to me is whether this is simply a temporary thing, simply a chance effort to meet a chance problem, or does it fall in with that general trend of events which one gradually gets to trust as being the best clue to the importance and the probable continuation of any movement that one sees an instance of in our midst. In an effort to test this trend I think it will be possible to see three things; first, that it belongs to a long movement, one that has gone over a long period of time; secondly, that it is a broad movement, that it is only one part of a whole series of changes; thirdly, that it is analogous to the great political movement that we have been so interested in in the last century and are still in the midst of, and that it therefore has whatever strength the political movement toward democracy possesses.

\section{The Governing Class in England}

To show those facts as they seem to me, I intend to go to English examples. English examples are more available than American examples for two or three reasons. One is that England has only one legislature, and her legislation is, therefore, a simpler problem; whereas we have some forty-nine. Another reason is that they were earlier on the ground than we in most of these things. Most political phenomena and, I think, all economic phenomena of recent times have shown them- selves first in England. Then again it is easier to stand off and look at what somebody else is doing than to analyze and classify the occurrences of which we are ourselves a part.

As everybody knows, a hundred years ago, if we can take that large a span, England was subject to a class government. She possessed an aristocratic type of political government. Out of the 12,000,000 people in England at that time, if you took about 100,000 , you would find in that group all the members of Parliament and those who were influential in elections, all the members of the ministry, all diplomatic representatives abroad, all the judges on the bench and the minor judiciary of the country, all the officers in the army and navy, all the clergy of the established church, all the professors and students in the universities and in the great public schools. From almost every point of view you chose to look at persons of political or social influence you would find them a closed circle. A comparatively small number of persons were controlling the political destiny of England and all other phases of society that fall naturally in with its political fortunes. England, in other words, had an aristocratic form of government in which 12,000 000 people were governed by about one-hundreth of their own number. Only about one grown man in eight was a voter. Political aristocracy was nearly complete. The members of it were proud of their success. They pointed with pride to the great wars which they had carried through successfully and to what they considered 
their good government. The Duke of Wellington, who was Prime Minister in 1830, said that if he were asked to make a government for any country he would not say that he would make a government like that of England, because the power of man could not accomplish that, but he would make a government just as nearly like that of England as could be. The reason it was such a good government was because property was so largely represented, especially landed property.

\section{The Economic Governing Class in ENGLAND}

Such was the position and such was the attitude of the governing class of England. That is familiar, but I do not think we are quite so familiar with the fact that, looked at from an economic point of view, exactly the same thing was true in England one hundred years ago. The country was under a narrow class government. If you should have taken 100,000 people, or probably a much smaller number than that, you would have found in that 100,000 persons all those who had any effective control over the economic concerns of England-all the manufacturers in the larger forms of industry, all the mine owners, all the owners of the railroads that were just then being laid, all the owners of the steamship lines that were just then being established. Looked at from every point of view that has to do with the industrial life of a nation, including all the great landlords of the country, you would find that it was again a closed circle. The actual numbers I do not think it is practicable to obtain, but, certainly they were much less than 100,000 persons. Sometimes they were the same as the political aristocracy. Lord Melbourne, for instance, was not only Prime Minister of England but one of the largest coal mine owners in
England. You may find other instances where the two classes lap over each other, though in most cases this was not true. However, if you took those 100,000 persons or fewer, they had very much the same position in economic concerns that the political aristocracy which governed England had in its political concerns.

They were alike proud of their success and alike approved by the dominant spirit of the times. Circumstances had so worked out that the new inventions of the industrial revolution had come, not into the hands of the whole community, as seems to have been anticipated by the earlier inventors and the organizations which offered prizes for new inventions, but had come into the hands of a certain group of persons. The prevailing view of laissez-faire was that the government was to leave economic concerns alone. But laissez-faire as usually interpreted means to leave things alone as they are at any one time. It does not mean to let everybody start fresh from scratch; it means to leave some people with a very heavy handicap and other people with very great advantages. To "leave things alone at that time meant to leave the control of the newly organized industry to those persons who, by family connection or by inheritance, or by other opportunity were able to obtain capital. Moreover, laissez-faire meant to leave them with the political system of the time intact, a system of government by the few, government by an aristocracy. When the workmen began to form combinations the employers appealed, in the first place, to an aristocratic and, therefore, sympathetic legislature. Parliament, thereupon, strengthened the old combination acts. Then they appealed to the courts and the opposition of the common law to any kind of organization. I presume there never 
has been any such body of class law in the world as the English common law as it was as late as a century ago. It was the law of the state as against the individual citizen. It was the law of the landlord as against the tenant. It was the law of the employer as against the employee. It was the law of the husband as against the wife, of the man as against the woman. The relations of economic classes were then under the domination of the law of the time, the common law, and of statutes that were being adopted from time to time by an aristocratic legislature.

In 1810 the journeymen printers on the London Times struck for higher wages. A number of them were prosecuted under the combination laws and were sentenced to imprisonment for periods from nine months to two years. Sir John Sylvester, the judge, when sentencing them said: "Prisoners, you have been convicted of a most wicked conspiracy to injure the most vital interests of those very employers who gave you bread.

The frequency of such crimes among men of your class of life and their tendency to ruin the fortunes of those employers, which a principle of gratitude and self-interest should induce you to support, demand of the law that a severe example should be made." That is, employers were a class who gave bread to another class-the workingmen. A certain magistrate who was also a mine owner, reporting to the Home Secretary in 1830 concerning a strike against the truck system writes, "I shall have the men apprehended who have left their employ and have them sent to the treadmill." Not only was there a governing and a governed class industrially, but the former were also considered to be, as in the case of aristocratic political government, the patrons and benefactors of the workingmen and of the community as well. A judge in 1816, sentencing nine hatters of Stockport to two years imprisonment for combining to stop work till their employer, a William Jackson, should pay them better wages, said, "A person who, like Mr. Jackson, has employed from one hundred to one hundred and thirty hands, common gratitude would teach us to look upon as a benefactor of the community."

In a certain sense and at first sight the pride of the manufacturers and railway and mine owners and the support of them in their class domination by the rest of the community was justified. The myth that labor was merely a commodity to be bought, like fuel and raw material, by employers, and put to the most effective use for purposes of production, was all but universally accepted.

The workingmen themselves, like others, glad to be credited with something of their own and easily led astray by a figure of speech, accepted the delusion that their work could be bought and sold apart from their personality, and that they had no interest and responsibility for its use after the contract was once made or implied.

\section{The Effect of Economic ARIstocracY}

The capitalists or managing employers were thus credited with being the producers of wealth and it was believed they were making England rich. In a certain sense England was becoming a rich country. But, individually speaking, it was only rich at the top. Further down, just as in the rural districts of England during the period of the domination of the landlord, you find the most impoverished, the most miserable and the most demoralized peasantry of the world, so, industrially, the first half of the nineteenth century was one of the worst periods 
in economic history. It is true that there was a large amount of wealth in England and it was somewhat widely distributed among a certain upper and upper middle class, but below these there was a vast mass of povertypoverty to the extent of absolute destitution, extreme irregularity of employment, and miserable conditions of living.

I may say frankly that there was a long period in which I did not believe that this was the condition of England. I believed that the general effect of the industrial revolution was to raise the mass of the people industrially; but the more I study this period the more I am convinced that this is a mistake. The effect of the introduction of machinery and of large amounts of capital and the adoption of a new industrial organization was, for the time at least, and under the influence of laissez-faire, deleterious to the masses of the people. England had a great body of population, overworked, underpaid, underfed, uneducated and untrained, without opportunity and without incentive. It was a very miserable population compared even with the masses on the continent of Europe at the time. I should be sorry to give the impression that I am imputing any especial blame to the capitalist managers of industry of that period, any more than blame is to be attached to the aristocratic rulers of England in a political sense. The question is not an ethical but an institutional one. A man might be a good or a bad man individually, or, like most of us, partly good, partly bad, but his larger business relations must be carried on under the dominating conditions of his time.

Disappearance of Political ArisTOCRACY

I have tried to make it clear that two or three generations ago England was under class government. This governing class, whether looked at from a political point of view or an economic point of view, consisted of a small group of persons who dominated all the interests of the English people. It is from this state of things that modern conditions emerge. The fact that aristocracy has passed away in a political sense is familiar. A great series of Parliamentary reform bills, the bill of 1832, the bill of 1867 and the bill of 1884 gradually extended the right to vote throughout England.

The Parliament act of 1911 gave the popular house, the House of Commons, power over the House of Lords, so that the House of Lords can now do nothing more than block the House of Commons for two years; and the Representation of the People Act of 1918 extended the right of voting to practically all persons who had not possessed it before. It included the previously disfranchised half of humanity, so that women are now represented as well as men; and took away plural voting, so that each person has only one vote. It practically equalized the electoral districts, so that since 1918, I presume England stands out in form of government the most complete democracy of any large nation that exists in the world or ever has existed. For the old political aristocracy the degree of democracy so far attained has been gradually substituted. It is only an embryonic form of democracy, but, at least, we have made a good beginning that is easily recognizable now. The same thing has been occurring in the other realm of ancient aristocracy, the economic field. This has not been, however, so simple a process, nor is it quite so easy to follow. Yet if we will look at it we will see, I think, that England and, less consistently, other countries have passed through very nearly the same series of phenom- 
ena. A hundred years ago an employer, the man who provided the capital, might say, "This is my business. I will carry it on as I see fit, I will engage such people as I choose and I will discharge them when and how I choose, and I will carry the business on during such hours as I choose to carry it on. I will go into any line of business that pleases me. Hours, wages, prices, materials, labor conditions and marketing conditions, what I pay for labor and what I charge for my products are my own affairs and mine alone. My business is my inviolable personal property." He could say this with a certain amount of truth and a certain amount of general approval. But how long could he continue to say it? That is the question.

\section{Effect of the Factory Acts}

As early as 1802 the first of the Factory Acts was passed. It was very slight but factory legislation gradually extended from bound children to free children, from children to those of 18 years of age, then to women. It extended to sanitary conditions of factories, to matters of machinery, ventilation, prevention of accidents, use of materials; it extended to mines, and as late as 1912 we have it extended to ordinary retail stores and restaurants, providing for holidays and scores of requirements as well as for hours of labor. Any employer who now or at any time within the last fifty years should say, as employers often do, "I started this business and I will carry it on as I see fit," will realize if he stops to think that he is saying something which he cannot support by facts. Some great power has intervened, some external force, like the force of nature, has intervened and taken away from him his power to carry on his business as he sees fit. It allows him to engage only persons of certain ages, it does not allow him to carry on his work at night, it makes him shut up his shop on Saturday afternoons. A little chit of a girl can come into his factory or shop and say, "I am a representative of the Labor Department," and immediately he has to show her all over the place so that she can see if things are run, not as he wants them run, but in a way that is satisfactory to her; to see if the water is running, if there are enough chairs, and if there are rest rooms for girls, etc. She is a small representative of a large power. The government has come in and taken away from employers their control of many of the conditions of labor.

\section{InCRease of Government Functions}

This is only one of many ways in which the state has intervened. The state has come in to say that if an accident occurs in a place the employer has to pay an indemnity, has to pay a certain amount toward the support of the persons who are injured or lost in the industry; that is to say, the cost of accidents in industry are incumbent on the person who provides the capital that carries on the industry. In England, every employer of labor is bound to pay a little something every week for each one of his employees as insurance against sickness, and in some trades against the lack of employment. One could go on with a long list of illustrations of the loss of control of industry by employers as individuals or as a class. The government has taken up part of the field of occupation. In 1861 the government started in with the Government Savings Bank. It then bought up the telegraphs, then the telephones. After this it took up the Parcel Post, then the government handed over the tramways largely to the local governments. 
By the Town Planning Act, passed a few years ago, any town or local government is at liberty to build dwellings, open up suburbs with waterworks and organize itself for all the purposes of living of its people. Thus the government has extended its field to compete in that of private industry. This is a great field, in which the old individual aristocratic control of business used to be carried on quite without interference. That field has been very much narrowed, very much invaded by other powers. Economic aristocracy does not flourish as it did once.

\section{The Coöperative Movement in ENGLAND}

Moreover, since 1844 there has arisen a rival power, though it is probably seldom recognized as a rival power. It does not worry employers very much now, but it is a very real threat nevertheless. This is the growth of the coöperative movement. In England from the time when twentyeight weavers put in their pound a piece and bought some oatmeal and butter and other such groceries and began their little store, the coöperative movement has spread quietly but irresistibly like a flood. In 1864 they opened up their great wholesale store. Then they bought, one after another, the vessels which they sent to Holland, Denmark, and other countries to buy and transport goods. They opened up agencies in various countries. They bought up tea plantations in Ceylon and they own cotton lands in India. They own approximately 12,000 acres of farms in England. They have opened up factories for boots and shoes, woolen goods, flour, biscuits and a dozen other products. At the present time there are about 1,500 coöperative societies in England, with three and one-half million members. They have $\$ 350,000,000$ of share capi- tal, and last year did almost an even billion dollars worth of business. Cooperation is not to be despised by any means simply as a business movement. Moreover, the coöperators are the most ambitious people in the world, the most sanguine; they look forward to the future as a field for illimitable extension, both in business and politics.

In April of this year, it was reported that a committee of the coöperative organizations of England had entered into a combination with the Labor party and the Parliamentary Committee of the Trade Union Congress, in which they agreed, to act together in the formation of a political party. In 1917 the coöperators determined, after a quarrel with the present prime minister, to go into politics and to recommend representatives for parliamentary seats. They are not strong enough politically to accomplish very much alone, but with the rising Labor party and with the whole trade union movement back of them, their political potentialities in the future are great. Their ambitions correspond to the agreement made that the three groups "will support one another in their respective and combined efforts to set up a new social order, with the ultimate object of the establishment of a coöperative commonwealth." It must be remembered that, if business organized under capitalistic management does not succeed in making production continuous or in carrying it on satisfactorily to the community, there is a great competitor standing alongside of them who is not attracting very much attention at present, but who seems in many ways capable of meeting English conditions, especially war conditions and post-war conditions. So in measuring the passing away of the old aristocratic control of business by the individual capitalist employer, we will have to include the building up of 
this great democratic system of industry; a system of industry in which there is no employer; in which the same persons provide the management, the capital and the body of purchasers of the goods.

\section{The Trade Union Movement}

The trade union movement is more than a century old in England, but it was just a century ago that it obtained what is sometimes called its Magna Charta, the bill of 1825, which for the first time made collective bargaining legal - the bill which allowed the trade unions to exist lawfully and to carry on their ordinary and most simple functions. From that time the trade unions have been steadily more and more fully legalized. In 1871 there was the great legalizing statute, which recognized them as having the advantages of corporations; in 1875 there was the modification of the criminal law, which provided that nothing which organizations such as trade unions did was criminal unless it was criminal for an individual to do it. In 1901 there was an unexpected decision against the trade unions, by which it was found that their general funds could be levied upon for losses suffered by employers in connection with a trade struggle, but in $\mathbf{1 9 0 6}$ a law was passed in Parliament by which that decision was practically reversed, or, at least made inapplicable in the future. This provides that trade unions cannot be sued as unions for any action of their officers; that they cannot be sued for damages for any action that is carried on in connection with a trade struggle unless that action was illegal, and declares boycotts and picketing not illegal; so that the trade unions since 1905 practically cannot be interfered with by law in a civil sense, any more than they could since 1875 in a criminal sense. In 1909 there was another decision that came unexpectedly to them. This restricted their right to use their funds to a narrow group of purposes; but in 1913 again a law was passed in Parliament by which a new definition was given of what constituted a trade union. This law enables them at the present time to use their funds for practically anything they want to. Therefore, trade unions have been gradually made as completely legal as any other organized groups of citizens.

During the same time the growth of trade unions has been almost continuous, until at the outbreak of the war there were about $3,000,000$ organized trade unionists in England. In 1906 they had fifty-two "Labor" members in parliament, a number that has been increased to sixty-one at the present time.

The effect of the war on trade unions was apparently to intensify every form of their action, as it did almost everything else. The war has had very little effect on actually initiating movements in economics or politics or social life, but it has had a very great influence in increasing the rapidity of development of movements which were already in progress.

The war had four or five very distinct effects on the trade unions. In the first place it increased the number of trade unionists very rapidly. Large numbers of men joined the unions, especially after the second year of the war, so that now there are about $4,000,000$ regular dues-paying members. Again, it brought new groups of persons into the movement-clerks, bookkeepers, post-office employees, government clerks, "black-coated unions," as they are sometimes called in England; and a whole series of persons, who had not before participated in the trade union movement, have now formed unions. 
The war introduced a certain element of industrial unionism, and in 1919 Parliament passed a law making such amalgamations legal; that is to say, that organization of workmen should be by industries instead of by special crafts. It also increased the unwillingness of the rank and file of the working classes to obey orders, to submit to their officers. The series of events that we have seen within the last few weeks in the instance of the railroad strikers in this country is exactly what happened in England. Indeed it threatened to happen over and over again, right through the war, though successfully warded off each time. Trade unionists, however, are very restive, even under their own officers. Other effects were not less perceptible. The so-called "triple alliance" was formed. Three of the largest unions-the railroad workers with 650,000 members, the miners with over a million, and 250,000 transport workers-have not only been closely organized but they also have formed a combination, at least for defensive purposes. They have, as a matter of fact, never yet acted together, though they have recently acted one at a time. If they should ever act together, social and economic life in England would be paralyzed; it would have all the characteristics of a general strike.

Thus the war intensified all trade union movements, so that at the present time no employer can carry on his industry without dealing in some way or other with a union. Whether he likes it or not, whether he considers it good or bad, the fact is that the old aristocracy of economic life has come to an end, whether by intervention of the state, or by the rise of another element in industry into a position which makes it so powerful that it has to be carefully considered.

The remaining point that I want to mention as a result of the war is that in these latter days in England there has been a very visible spirit of democracy infused in all affairs. The readiness with which the proposed Whitley councils were accepted by employers, employees and the government is a good indication of this.

\section{Economic Democracy in England}

Finally, the state of affairs I have been trying to analyze is a continuous one. There has been no period of twenty years during the last one hundred years in which some contribution was not made to a more controlled social treatment of industrial conditions than existed before, or in which the old control of industrial affairs by the employers was not intruded upon in one way or another. An employer who now declares that the business in which his money is invested is his own, to do with as he wishes, without interference by others, is as impractical and is engaged in as hopeless a struggle against the spirit of the times as was Charles I, when on the scaffold he declared that government was no concern of the people, or the Duke of Wellington when he opposed the first reform bill on the ground that England already had the best possible form of government, because she was governed by her propertied classes. The spirit of democracy, the spirit of control by persons other than capitalist managers, is merely the final step up to the present time in English industrial development. It is quite evident that this movement has been going on for a long period, that it is not simply a momentary claim by the labor class, but has been carried on along three or. four lines, the rise of state control, rivalry of another form of industry growing up alongside of capitalistic industry, a self-assertion of the working classes and their insistence 
on having a larger amount to say in everything connected with industrial life. Such a continuous movement as this, so analogous to the movement for political democracy, so wide in its extent, cannot be expected to stop short of some great epoch-making change. It obviously has all the characteristics of evolution in human society. It is part of the organic growth of the community.

If we look from England to other countries we will find that we have to trace much the same steps, the same intrusion of the state, the same growth of the organized working classes, the same spirit of democracy coming into the public attitude toward industry, that there has been in England. Therefore, the trend toward industrial democracy, from the historian's viewpoint, is a general and permanent trend. It is a movement which has all the characteristics of long continuance, of wide application, of existence in many countries, of continuity and of rising force as the years have gone on, until we are now in the very thick of it. 